\title{
11: 71578250-71585014
}

National Cancer Institute

\section{Source}

National Cancer Institute. 11:71578250-71585014. NCI Thesaurus. Code C42290.

Physical location of FOLR1_Gene 